\section{Effect of Composts in Substrates on the Growth of Tomato Transplants}

\author{
Manuel Díaz-Pérez ${ }^{1}$ and Francisco Camacho-Ferre ${ }^{1,2}$
}

ADDITIONAL INDEX WORDs. peat, growing media, seedbed, solid urban waste, vegetable, vine pomace

SUMMARY. In this work, we studied the effect of different substrate mixes composed of blond peat and compost produced from solid urban waste, vegetable waste, and vine pomace on the quality of tomato seedlings (Solanum lycopersicum $\mathrm{cv}$. Dakapo). Each compost was mixed with blond peat at different ratios such that the initial electric conductivity (EC) of the final mixes was $2.5,3.5$, and $4.5 \mathrm{dS} \cdot \mathrm{m}^{-1}$. The following control substrates were used: blond peat and blond peat + black peat + standard coconut fiber used in commercial nurseries on experimental basis. Emergence and several seedling quality variables were monitored. Results showed that peat in nursery substrates can be partially substituted by these composts to grow tomato seedlings. The quantity of vegetable waste and vine pomace compost used should not allow the initial EC to exceed $2.5 \mathrm{dS} \cdot \mathrm{m}^{-1}$.

$\mathrm{E}$ fficient production of horticultural seedlings in nurseries requires plants that can develop rapidly and uniformly until they are well established. To that end, the role played by substrates is critical (Sterrett, 2001). Many materials, alone or mixed, can be used to produce substrates with the appropriate physical, chemical, and biological characteristics to grow different crops under diverse cultural conditions (Burés, 1997). Currently, sphagnum peat provides the base material for the majority of commercial substrates used in nurseries; its excellent physical, chemical, and biological properties make it ideal for growing horticultural seedlings (Abad et al., 2001; Burés, 1997). Peat is collected from bogs, marshes, and wetlands, which are often fragile ecosystems of great ecological and archaeological value (Bustamante et al., 2008). Unfortunately, the high demand for peat in horticulture has led to constant exploitation of peatlands, the consequent depletion of this resource, and the ecosystem degradation (Raviv, 1998; Sterrett, 2001). Since the late 1970 s, alternatives to peat have been sought worldwide (Raviv et al., 1986).

Many authors have indicated the viability of vegetable waste composts (VW), solid urban wastes (UW), and the residues of the wine industry [vine

${ }^{1}$ Plant Production in Mediterranean Crop Systems Research Group, Advanced Polytechnic School, University of Almeria, Almeria 04120, Spain

${ }^{2}$ Corresponding author. E-mail: fcamacho@ual.es. pomace (VP)] as seedbed substrates for the production of horticultural seedlings in nurseries (Castillo et al., 2004; García-Gómez et al., 2002; Herrera et al., 2008; Kostow et al., 1996; Pérez-Murcia et al., 2006). The use of these composts also helps solving a major environmental problem: their disposal. Every year, Europe alone produces more than 1.8 billion megagrams of total waste $-3.5 \mathrm{Mg}$ of waste per person (Bernal and Gondar, 2008).

Immaturity and instability are common problems of composts when used as seedbed substrates for horticultural seedlings (Carmona and Abad, 2008). Even well-stabilized compost can have properties considered to be limiting factors for horticultural use, such as the presence of heavy metals, low water-holding capacity, aeration problems, or excessive content of salt and nutrients (Carmona and Abad, 2008; GarcíaGómez et al., 2002). The use of very saline substrates to grow tomato seedlings can lead to physiological, morphological, and biochemical abnormalities. Effects of salinity on tomato seed germination are closely linked to the substrate's concentration, the species, and the cultivar used (Cuartero and Fernández-Muñoz, 1999; Foolad and Lin, 1997; Srinivas, 2001), as well as plant height, leaf number, stomatal density, leaf area (Al-Karaki, 2000; Romero-Aranda et al., 2001), and root development. When the damage caused is severe, chlorosis and necrosis appear, especially at the leaf edges (Al-Karaki, 2000; Romero-Aranda et al., 2001). Combining peat with compost can attenuate some of the physical and chemical problems that composts present when used alone (Bustamante et al., 2008; Raviv et al., 1986).

Several authors have shown the viability of UW, VW, and VP as components of substrate mixes for tomato seedlings (Castillo et al., 2004; Herrera et al., 2008; Kostow et al., 1996). Herrera et al. (2008) reported that a mixture of $30 \% \mathrm{UW}$, $65 \%$ peat, and $5 \%$ perlite $(\mathrm{v} / \mathrm{v})$ allowed the production of tomato plants with development properties similar to those produced using the common nursery substrate mix of blond peat, black peat, and coconut fiber. In addition, these authors also noted that to reduce the negative effects of the high electrical conductivity $\left(\mathrm{EC} ; 11.4-19.8 \mathrm{dS} \cdot \mathrm{m}^{-1}\right.$ ) and $\mathrm{pH}$ (8.1-8.8) of their compost, the ratio of the compost component should not exceed 30\% (v/v). Ribeiro et al. (2007) evaluated a compost obtained from forestry waste and solid swine manure $\left(\mathrm{EC}=0.27 \mathrm{mS} \cdot \mathrm{cm}^{-1}, \mathrm{pH}\right.$ 6.88) as a substrate for the production of tomato seedlings. The greatest

\begin{tabular}{llll}
\hline $\begin{array}{l}\text { Units } \\
\begin{array}{l}\text { To convert U.S. to SI, } \\
\text { multiply by }\end{array}\end{array}$ & U.S. unit & SI unit & $\begin{array}{l}\text { To convert SI to U.S., } \\
\text { multiply by }\end{array}$ \\
\hline 3.7854 & gal & $\mathrm{L}$ & 0.2642 \\
2.54 & inch(es) & $\mathrm{cm}$ & 0.3937 \\
25.4 & inch $(\mathrm{es})$ & $\mathrm{mm}$ & 0.0394 \\
6.4516 & inch $^{2}$ & $\mathrm{~cm}^{2}$ & 0.1550 \\
0.2276 & inch $^{2} / \mathrm{oz}$ & $\mathrm{cm}^{2} \cdot \mathrm{g}^{-1}$ & 4.3942 \\
1 & $\mathrm{mmho} / \mathrm{cm}$ & $\mathrm{dS} \cdot \mathrm{m}^{-1}$ & 1 \\
28.3495 & $\mathrm{oz}$ & $\mathrm{g}$ & 0.0353 \\
28,350 & $\mathrm{oz}$ & $\mathrm{mg}$ & $3.5274 \times 10^{-5}$ \\
1.0012 & $\mathrm{oz} / \mathrm{ft}^{3}$ & $\mathrm{~kg} \cdot \mathrm{m}^{-3}$ & 0.9988 \\
0.001 & $\mathrm{ppm}$ & $\mathrm{g} \cdot \mathrm{L}^{-1}$ & 1000 \\
1 & $\mathrm{ppm}$ & $\mathrm{mg} \cdot \mathrm{L}^{-1}$ & 1 \\
0.9072 & $\mathrm{ton}(\mathrm{s})$ & $\mathrm{Mg}$ & 1.1023 \\
$\left({ }^{\circ} \mathrm{F}-32\right) \div 1.8$ & ${ }^{\circ} \mathrm{F}$ & ${ }^{\circ} \mathrm{C}$ & $\left(1.8 \times{ }^{\circ} \mathrm{C}\right)+32$
\end{tabular}


growth was achieved with $100 \%$ composted substrate, while the least growth was achieved with peat alone. Castillo et al. (2004) reported that $\mathrm{pH}$, salinity, and organic matter content of UW have great influence on the quality of tomato seedlings. In addition, they reported that EC values of more than $9 \mathrm{dS} \cdot \mathrm{m}^{-1}$ were associated with plants of poorer quality.

The above-mentioned studies suggest that the partial substitution of peat by composts for tomato seedlings production is feasible. However, they failed to define the optimal ratios with respect to the physical and chemical properties of such composts. The aim of the present work was to examine the effect of seedbed substrates with several EC values on the growth of tomato seedlings, based on different peat, UW, VW, and VP compost ratios.

\section{Materials and methods}

These experiments were performed in a multitunnel greenhouse at a specialized nursery in Almería, Spain. UW, VW, and VP composts used were obtained from commercial composting plants. All composts were sieved to eliminate particles larger than $5 \mathrm{~mm}$ in diameter. They were then individually mixed with blond peat, perlite, and vermiculite at different ratios until substrates with an $\mathrm{EC}$ of $2.5,3.5$, and $4.5 \mathrm{dS} \cdot \mathrm{m}^{-1}$ were produced (Tables 1 and 2 ). Two control substrates were also prepared: one with blond peat, black peat, and coconut fiber (the standard substrate used at the experimental station), and another substrate based on blond peat. Final substrate ratios are shown in Table 1, while the chemical characteristics of the treatments are shown in Table 2.

EC of the saturated extracts obtained from these substrates was determined using the method of Richards (1954) and Scofield (1940). EC values of the compost mixtures were established taking into account an optimum salinity of 3 to $5 \mathrm{dS} \cdot \mathrm{m}^{-1}$ for the substrate solution, as described for horticultural plants by Abad et al. (2004), and the $<3.5 \mathrm{dS} \cdot \mathrm{m}^{-1}$ maximum value of the saturated extract for seedbed substrates described by Lemaire et al. (1985) and Wright (1986).

Seedlings were grown in expanded polystyrene trays with 150 wells lined with single-use polypropylene sleeves. The wells were manually filled with substrate; in contrast, seeds were sown mechanically with one 'Dakapo' tomato seed per well. Seeds were sown on 19 Aug. 2007 (Expt. 1) or 6 Sept. 2008 (Expt. 2). The sowing depth was $2 \mathrm{~mm}$. All the wells were then covered with an insulating and evaporation-reducing layer of vermiculite (no. 3 granules between $\mathrm{l}$ and $4 \mathrm{~mm}$ size with density between 60 and $90 \mathrm{~kg} \cdot \mathrm{m}^{-3}$ ).

Water was then added to saturate the substrate and the trays were placed in a pre-germination chamber at $27^{\circ} \mathrm{C}$ and $98 \%$ relative humidity for $5 \mathrm{~d}$. They were then removed and placed on greenhouse benches (height $60 \mathrm{~cm}$ ). In both experiments, $0.5 \mathrm{~L}$ of water with $1.3 \mathrm{dS} \cdot \mathrm{m}^{-1} \mathrm{EC}$ was applied through sprinkle irrigation during the first $10 \mathrm{~d}$ after sowing (DAS). From 11 DAS, fertigation was applied every day evenly (with microsprinklers) for all treatments. Fertilization was provided with 0.5 $\mathrm{g} \cdot \mathrm{L}^{-1}$ potassium nitrate $(13 \mathrm{~N}-0 \mathrm{P}-$ $38.2 \mathrm{~K})+0.3 \mathrm{~g} \cdot \mathrm{L}^{-1}$ potassium dihydrogen phosphate $(0 \mathrm{~N}-22.7 \mathrm{P}-27.4 \mathrm{~K})+$ $0.2 \mathrm{~g} \cdot \mathrm{L}^{-1}$ ammonium nitrate $(33.5 \mathrm{~N}-$ $0 \mathrm{P}-0 \mathrm{~K})$. The volume of water and fertilizers applied at the beginning was $0.5 \mathrm{~L} /$ tray. At $20 \mathrm{DAS}$, the volume was increased to $0.8 \mathrm{~L} /$ tray. Finally, on day 28 (DAS), the volume of water was increased to $1 \mathrm{~L} /$ tray, remaining at such a level until the end of the crop season.

Both experiments had a randomized block design with 11 treatments (Table 1) and four blocks (four trays consisting of 150 cells each); effects of the variable experiment were taken into account in the analysis of variance (ANOVA). Thus, in each experiment, 6600 seeds were sown. Trays were arranged in the central area of the greenhouse to avoid border effects.

To determine the chemical variation of each substrate over the two experiments, EC and $\mathrm{pH}$ were recorded before sowing and after the growth of the seedlings using a conductivity meter and a $\mathrm{pH}$ meter with a precision of 0.1 units (HI-9811; Hanna Instruments, Eibar, Spain).

In both experiments, percentage emergence (both cotyledons extended above the substrate) was assessed at 5, 7, 9, 11, and 13 DAS. The emergence rate was also calculated using the modified version of the Timson index: $\Sigma G / t$, where $G$ is the number of seeds that emerge in

Table 1. Composition of the substrate treatments used for production of tomato transplant in Almería, Spain in 2007 and 2008.

\begin{tabular}{|c|c|c|c|c|c|c|}
\hline \multirow[b]{2}{*}{ Treatments $^{\mathrm{z}}$} & \multicolumn{6}{|c|}{ Composition of the substrates $(\% \mathrm{v} / \mathrm{v})$} \\
\hline & Blond peat & Black peat & Coconut fiber & Compost & Perlite A-13 & Vermiculite \\
\hline $\mathrm{P}$ & 90 & 0 & 0 & 0 & 5 & 5 \\
\hline VW2.5 & 81 & 0 & 0 & 9 & 5 & 5 \\
\hline VW3.5 & 76 & 0 & 0 & 14 & 5 & 5 \\
\hline VW4.5 & 72 & 0 & 0 & 18 & 5 & 5 \\
\hline VP4.5 & 0 & 0 & 0 & 90 & 5 & 5 \\
\hline UW2.5 & 76 & 0 & 0 & 14 & 5 & 5 \\
\hline UW3.5 & 69 & 0 & 0 & 21 & 5 & 5 \\
\hline UW4.5 & 66 & 0 & 0 & 24 & 5 & 5 \\
\hline
\end{tabular}

${ }^{\mathrm{z}} \mathrm{P}=$ peat, $\mathrm{HNS}=$ habitual nursery substrate, $\mathrm{VW}=$ vegetable waste compost, $\mathrm{VP}=$ vine pomace compost, $\mathrm{UW}=$ solid urban waste compost; numbers $(2.5,3.5$, and 4.5$)$ following $\mathrm{VW}, \mathrm{VP}$, and $\mathrm{UW}$ indicate the initial electrical conductivity $\left(\mathrm{EC}_{\mathrm{i}}\right)$ of the saturated extract in $\mathrm{dS} \cdot \mathrm{m}^{-1}\left(1 \mathrm{dS} \cdot \mathrm{m}^{-1}=1 \mathrm{mmho} / \mathrm{cm}\right)$. 
Table 2. Chemical characteristics of the substrate treatments used for production of tomato transplants in Almería, Spain in 2007 and 2008.

\begin{tabular}{|c|c|c|c|c|c|c|c|c|c|}
\hline Treatments $^{\mathrm{z}}$ & $\begin{array}{c}\mathrm{EC} \\
\left(\mathrm{d} S \cdot \mathrm{m}^{-1}\right)^{\mathrm{z}}\end{array}$ & $\begin{array}{l}\text { Nitrates } \\
\left(\mathrm{mg} \cdot \mathrm{L}^{-1}\right)^{\mathrm{y}}\end{array}$ & $\begin{array}{l}\text { Sulfates } \\
\left(\mathbf{m g} \cdot \mathrm{L}^{-1}\right)\end{array}$ & $\begin{array}{c}\text { Chlorides } \\
\left(\mathrm{mg} \cdot \mathrm{L}^{-1}\right)\end{array}$ & $\begin{array}{l}\text { Phosphorus } \\
\left(\mathbf{m g} \cdot \mathrm{L}^{-1}\right)\end{array}$ & $\begin{array}{l}\text { Sodium } \\
\left(\mathrm{mg} \cdot \mathrm{L}^{-1}\right)\end{array}$ & $\begin{array}{l}\text { Potassium } \\
\left(\mathrm{mg} \cdot \mathrm{L}^{-1}\right)\end{array}$ & $\begin{array}{l}\text { Calcium } \\
\left(\mathrm{mg} \cdot \mathrm{L}^{-1}\right)\end{array}$ & $\begin{array}{c}\text { Magnesium } \\
\left(\mathrm{mg} \cdot \mathrm{L}^{-1}\right)\end{array}$ \\
\hline P & 0.62 & 20 & 296 & 23 & 29 & 29 & 79 & 111 & 15 \\
\hline HNS & 0.72 & 15 & 196 & 86 & 33 & 71 & 164 & 45 & 11 \\
\hline VW2.5 & 2.5 & 19 & 516 & 831 & 27 & 172 & 557 & 181 & 75 \\
\hline VW3.5 & 3.5 & 18 & 638 & 1280 & 26 & 251 & 823 & 221 & 108 \\
\hline VW4.5 & 4.5 & 17 & 735 & 1639 & 25 & 314 & 1035 & 252 & 134 \\
\hline VP4.5 & 4.5 & 3587 & 3020 & 1042 & 0 & 226 & 3110 & 420 & 105 \\
\hline UW2.5 & 2.5 & 63 & 1603 & 1161 & 24 & 611 & 545 & 557 & 86 \\
\hline UW3.5 & 3.5 & 85 & 2257 & 1729 & 22 & 902 & 778 & 780 & 121 \\
\hline UW4.5 & 4.5 & 94 & 2537 & 1973 & 21 & 1026 & 878 & 875 & 136 \\
\hline
\end{tabular}

${ }^{2} \mathrm{P}=$ peat, $\mathrm{HNS}=$ habitual nursery substrate, $\mathrm{VW}=$ vegetable waste compost, $\mathrm{VP}=$ vine pomace compost, $\mathrm{UW}=$ solid urban waste compost; numbers $(2.5,3.5$, and 4.5$)$ following VW, VP, and UW indicate the initial electrical conductivity $\left(\mathrm{EC}_{\mathrm{i}}\right)$ of the saturated extract in $\mathrm{dS} \cdot \mathrm{m}^{-1}\left(1 \mathrm{dS} \cdot \mathrm{m}^{-1}=1 \mathrm{mmho} / \mathrm{cm}\right)$.

${ }^{\mathrm{y}} 1 \mathrm{mg} \cdot \mathrm{L}^{-1}=1 \mathrm{ppm}$.

intervals of $2 \mathrm{~d}$ and $t$ is the total time over which emergence was recorded (Khan and Ungar, 1998). At the end of the growth period $(34 \mathrm{~d}), 16$ seedlings per tray were randomly selected and the following variables were recorded: plant height (from the soil surface to the tip of the seedling), stem diameter measured just under the cotyledons using a digital caliper (sensitivity $=0.1 \mathrm{~mm}$, model CDE300; Medid Precision, Barcelona, Spain), etiolating ratio (height/diameter), number of leaves per seedling (excluding the cotyledons), total leaf area per seedling measured using Photoshop CS3 Extended software (Adobe Systems, San Jose, CA), and total dry weight, root dry weight, stem dry weight, and leaf dry weight using a balance (sensitivity $=0.0001 \mathrm{~g}$, model AB54-S; Mettler-Toledo International, Basel, Switzerland) after drying the plants in an oven at $80{ }^{\circ} \mathrm{C}$ for $48 \mathrm{~h}$. The distribution of weight between the different parts of the plant was calculated, as well as the specific leaf area [SLA (the leaf surface area per unit of dry leaf weight)] and the leaf area/ total dry weight ratio (LADMR). Both ratios can be used to assess resistance to transplantation stress; smaller values indicate greater stress vulnerability (Herrera et al., 2008).

Data collected in both experiments were subjected to two types of ANOVA. In the first experiment, 11 treatments were analyzed according to the linear model $Y_{\mathrm{ijk}}=\mu+\alpha_{\mathrm{I}}+$ $\beta_{\mathrm{j}}+(\alpha \beta)_{\mathrm{i} j}+\tau_{\mathrm{k}}+\varepsilon_{\mathrm{ijk}}$ where $\mathrm{Y}_{\mathrm{ijk}}$ is the ijk-th observation, $\mu$ is the overall mean of the variable in question, $\alpha_{i}$ is the effect of the $\mathrm{i}$-th treatment, $\beta_{\mathrm{j}}$ is the effect of $j$-th experiment, $(\alpha \beta)_{\mathrm{ij}}$ is the effect of the interaction treatment $\times$ experiment, $\tau_{\mathrm{k}}$ is the effect of the $\mathrm{k}$-th block, and $\varepsilon_{\mathrm{ijk}}$ is the experimental error. The second type of ANOVA experiment assessed the effect of the interaction compost type $\times \mathrm{EC}_{\mathrm{i}}$. Therefore, the control treatments $P$ and HNS (see Table 1) were not taken into account. The linear model for this analysis was $Y_{\mathrm{ijk} l}=\mu+\alpha_{\mathrm{I}}+\beta_{\mathrm{j}}+$ $(\alpha \beta)_{\mathrm{ij}}+\tau_{\mathrm{k}}+\gamma_{1}+\varepsilon_{\mathrm{ijkl}}$ where $\mathrm{Y}_{\mathrm{ijkl}}$ is the ijkl-th observation, $\mu$ is the overall mean of the variable in question, $\alpha_{i}$ is the effect of the $\mathrm{i}$-th compost, $\beta_{\mathrm{j}}$ is the effect of the $\mathrm{j}$-th EC, $(\alpha \beta)_{\mathrm{ij}}$ is the effect of the interaction compost type $\times \mathrm{EC}_{\mathrm{i}}, \tau_{\mathrm{k}}$ is the effect of the $\mathrm{k}$-th block, $\gamma_{1}$ is the effect of l-th experiment, and $\varepsilon_{\mathrm{ijkl}}$ is the experimental error. The analysis of variance was carried out using the data of both experiments. Comparison between mean results for each treatment was undertaken using the multiple range tests (least significant difference method) (Gómez and Gómez, 1984). All calculations were made using Statgraphics software (version 4.0; Statpoint Technologies, Warrenton, VA).

\section{Results and discussion}

Chemical PROPERTIES ( $\mathrm{PH}$ AND EC) of the substrates. Significant differences were found between the substrates in terms of initial $\left(\mathrm{pH}_{\mathrm{i}}\right)$ and final $\left(\mathrm{pH}_{\mathrm{f}}\right) \mathrm{pH}$ (Table 3$)$.

$\mathrm{pH}_{\mathrm{i}}$ varied from 6.08 to 7.58 , and $\mathrm{pH}_{\mathrm{f}}$ from 6.3 to 7.4 (Table 3 ). These values are slightly higher than the 5.3 to 6.5 considered to be the optimum level for seedbed substrates (Abad et al., 2001). Other authors indicate that most greenhouse crops grow better in substrates with a $\mathrm{pH}$ of 5.2 to 7.0 (Raviv et al., 1986). The final EC values of the saturated extract $\left(\mathrm{EC}_{\mathrm{f}}\right)$ and their increase with respect to $\mathrm{EC}_{\mathrm{i}}$ was determined (Table 3 ). No significant differences were found between the $\mathrm{EC}_{\mathrm{f}}$ values for any of the substrates investigated, which ranged between 4.6 and 6.6 $\mathrm{dS} \cdot \mathrm{m}^{-1}$ (Table 3 ). These values are higher than the $3.5 \mathrm{dS} \cdot \mathrm{m}^{-1}$ recommended by Lemaire et al. (1985) and Wright (1986) as the limit for optimum growth and development of seedlings in nurseries, but below the limit of $8 \mathrm{dS} \cdot \mathrm{m}^{-1}$ proposed by Cuartero and Fernández-Muñoz (1999) for tomato crops. A greater change in EC was observed for substrates having a lower $\mathrm{EC}_{\mathrm{i}}$ (Table 3 ). These results show that salts added in fertilization that are not absorbed by the plant accumulate and remain in the substrate until a certain concentration value is reached and the excess is eliminated by leaching.

EFFECT OF SUBSTRATES ON PLANT EMERGENCE AND THE EMERGENCE RATE. Seedling emergence was significantly affected by the substrate (Fig. 1). Increase of $\mathrm{EC}_{\mathrm{i}}$ in the substrate mix delayed the emergence, thus reducing the emergence rate in tomato seeds (Table 4, Fig. 1). The emergence rate and the germination percentage were strongly related to the $\mathrm{EC}_{\mathrm{i}}$ of the substrate (Cuartero and Fernández-Muñoz, 1999). At 13 DAS, the emergence percentage was $>95 \%$ in all substrates except for those 
Table 3. $\mathrm{pH}$ and electrical conductivity (EC) of the different substrate mixtures used for production of tomato transplants before and after the growth period. Mean $\mathrm{EC}$ at the end of the seedling growth period $\left(\mathrm{EC}_{\mathrm{f}}\right)$ and increase in $\mathrm{EC}\left(\Delta \mathrm{EC}=\mathrm{EC}_{\mathrm{f}}-\right.$ $\left.\mathrm{EC}_{\mathrm{i}}\right)$ with respect to the initial $\left(\mathrm{EC}_{\mathrm{i}}\right)$ of the different treatments. Mean $\mathrm{pH}$ at the start and the end of the seedling growth period $\left(\mathrm{pH}_{\mathrm{f}}\right)$ and increase in $\mathrm{pH}\left(\Delta \mathrm{pH}=\mathrm{pH}_{\mathrm{f}}-\mathrm{pH}_{\mathrm{i}}\right)$ with respect to the initial $\left(\mathrm{pH}_{\mathrm{i}}\right)$ of the different treatments. $(\mathrm{n}=8)$.

\begin{tabular}{|c|c|c|c|c|c|}
\hline Treatments $^{\mathrm{z}}$ & $\mathrm{EC}_{\mathrm{f}}\left(\mathrm{dS} \cdot \mathrm{m}^{-1}\right)^{\mathrm{z}}$ & $\Delta \mathrm{EC}\left(\mathrm{dS} \cdot \mathrm{m}^{-1}\right)$ & $\mathrm{pH}_{\mathrm{i}}$ & $\mathrm{pH}_{\mathrm{f}}$ & $\Delta \mathrm{pH}$ \\
\hline $\mathrm{P}$ & $6.4 \mathrm{a}$ & $5.8 \mathrm{a}$ & $6.83 \mathrm{~cd}$ & $6.55 \mathrm{bcd}$ & $-0.28 \mathrm{bc}$ \\
\hline HNS & $6.2 \mathrm{a}$ & $5.5 \mathrm{a}$ & $6.54 \mathrm{de}$ & $6.46 \mathrm{bcd}$ & $-0.09 \mathrm{~b}$ \\
\hline VW2.5 & $6.3 \mathrm{a}$ & $3.8 \mathrm{bc}$ & $6.08 \mathrm{f}$ & $6.31 \mathrm{~d}$ & $0.23 \mathrm{a}$ \\
\hline VW3.5 & $6.1 \mathrm{a}$ & $2.6 \mathrm{cde}$ & $6.09 \mathrm{f}$ & $6.35 \mathrm{~cd}$ & $0.26 \mathrm{a}$ \\
\hline VW4.5 & $6.2 \mathrm{a}$ & $1.7 \mathrm{ef}$ & $6.14 \mathrm{ef}$ & $6.43 \mathrm{bcd}$ & $0.29 \mathrm{a}$ \\
\hline VP2.5 & $5.8 \mathrm{a}$ & $3.3 \mathrm{bcd}$ & $7.06 \mathrm{bc}$ & $6.66 \mathrm{~b}$ & $-0.40 \mathrm{c}$ \\
\hline UW2.5 & $6.6 \mathrm{a}$ & $4.1 \mathrm{~b}$ & $7.58 \mathrm{a}$ & $7.17 \mathrm{a}$ & $-0.41 \mathrm{c}$ \\
\hline UW3.5 & $6.3 \mathrm{a}$ & $2.8 \mathrm{cde}$ & $7.50 \mathrm{ab}$ & $7.36 \mathrm{a}$ & -0.14 bc \\
\hline UW4.5 & $5.5 \mathrm{a}$ & $1.0 \mathrm{fg}$ & $7.56 \mathrm{a}$ & $7.39 \mathrm{a}$ & $-0.17 b c$ \\
\hline Significance $^{\mathrm{y}}$ & NS & $* * *$ & $* * *$ & $* * *$ & ** \\
\hline
\end{tabular}

${ }^{2} \mathrm{P}=$ peat, $\mathrm{HNS}=$ habitual nursery substrate, $\mathrm{VW}=$ vegetable waste compost, $\mathrm{VP}=$ vine pomace compost, $\mathrm{UW}=$ solid urban waste compost; numbers $(2.5,3.5$, and 4.5$)$ following VW, VP, and UW indicate the initial electrical conductivity $\left(\mathrm{EC}_{\mathrm{i}}\right)$ of the saturated extract in $\mathrm{dS} \cdot \mathrm{m}^{-1}\left(1 \mathrm{dS} \cdot \mathrm{m}^{-1}=1 \mathrm{mmho} / \mathrm{cm}\right)$.

${ }^{y}$ ANOVA taking into account the 11 treatments according to the model $Y_{\mathrm{ijk}}=\mu+\alpha_{\mathrm{I}}+\beta_{\mathrm{j}}+(\alpha \beta)_{\mathrm{i}} \mathrm{j}+\tau_{\mathrm{k}}+\varepsilon_{\mathrm{ijk}}$. Ns $=$ not significant; * , * , ** $P \leq 0.05,0.01$, and 0.001 , respectively.
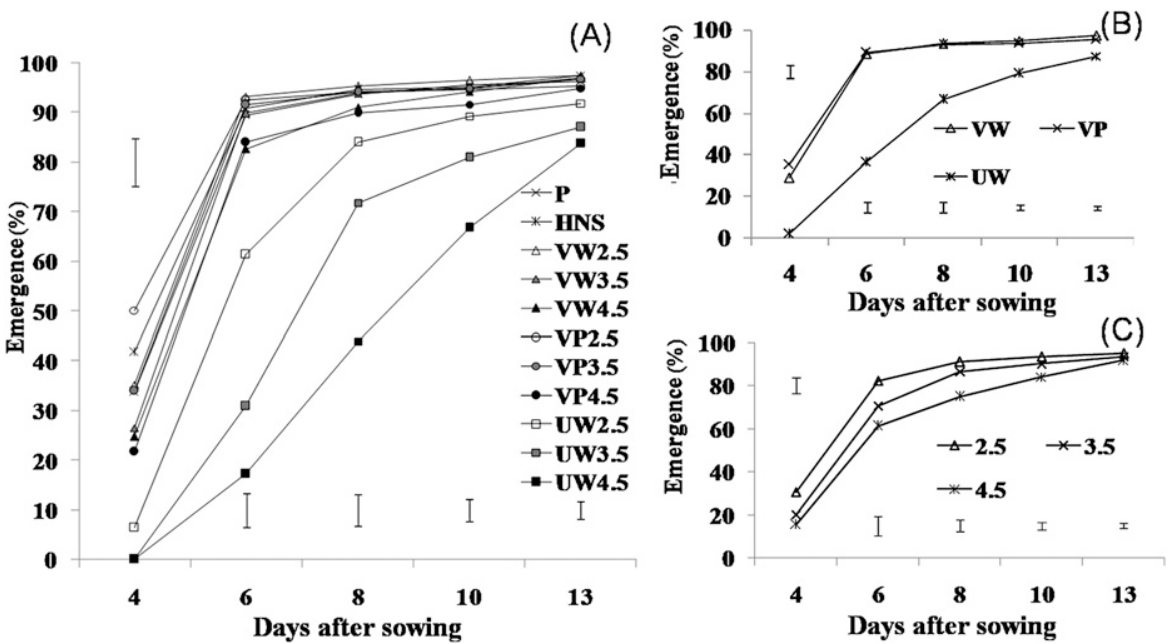

Fig. 1. (A) Emergence of the tomato seedling in the different treatments $(n=4)$; $\mathbf{P}=$ peat, $\mathrm{HNS}=$ habitual nursery substrate, $\mathrm{VW}=$ vegetable waste compost, $\mathrm{VP}=$ vine pomace compost, and UW = solid urban waste compost; VW, VP, and VW followed by $2.5,3.5$, and 4.5 indicate the initial electrical conductivity $\left(\mathrm{EC}_{\mathrm{i}}\right)$ of the saturated extract in $\mathrm{dS} \cdot \mathrm{m}^{-1}$. (B) Effect of substrate on tomato emergence $(\mathbf{n}=12)$. (C) Effect of substrate $\mathrm{EC}_{\mathrm{i}}\left(2.5,3.5\right.$, and $\left.4.5 \mathrm{dS} \cdot \mathrm{m}^{-1}\right)$ on tomato emergence $(\mathrm{n}=$ 12); $1 \mathrm{dS} \cdot \mathrm{m}^{-1}=1 \mathrm{mmho} / \mathrm{cm}$.

containing UW (3.5 and 4.5), all of which had significantly smaller values (even compared with the controls). The final germination percentage was smaller in the UW3.5 and UW4.5 mixtures (Table 4, Fig. 1). Differences were found between the $\mathrm{EC}_{\mathrm{i}}$ values of the UW compost and the other two composts, VW and VP, as well as between 2.5 and $4.5 \mathrm{dS} \cdot \mathrm{m}^{-1}$. Besides, significant interaction between compost type $\times \mathrm{EC}_{\mathrm{i}}$ was shown, leading to a differential effect only between compost UW and $\mathrm{EC}_{\mathrm{i}}(\mathrm{Ta}-$ bles 4 and 5 ). Nitrogen compounds dissolved in the substrate promote seed germination (Bethke et al., 2006; Hendricks and Taylorson, 1974). However, this was not the case in our experiments because there were no germination differences between the treatment with the highest nitrate concentration (VP4.5) and the treatment with the lowest nitrate concentration (HNS). The fact that at similar $\mathrm{EC}_{\mathrm{i}}$ values $(2.5,3.5$, or 4.5$) \mathrm{VW}$ and VP composts showed different emergency rates than the UW compost might have been caused by a higher presence of sodium and chlorine in the mix, just as it happened with the UW compost (Table 2).
EFFECT OF SUBSTRATES ON SEEDLING MORPHOLOGY. $\mathrm{pH}$ and $\mathrm{EC}_{\mathrm{i}}$ of the compost mixtures have a direct impact on seedlings' morphology and may affect their height, diameter, and the height/diameter ratios (Tables 4 and 5). In both experiments, taller plants were produced with treatments VW3.5 $(13.6 \mathrm{~cm})$, VW4.5 $(14 \mathrm{~cm})$, and VP2.5 $(13.9 \mathrm{~cm})$, while the shortest plants were produced with treatment UW4.5 $(9.3 \mathrm{~cm})$. Plants of treatments VW4.5 and VP2.5 were significantly taller than those in the blank control (treatment P), while those of treatments UW3.5 and UW4.5 were significantly smaller (Table 4). Seedlings of HNS, UW3.5, and UW4.5 treatments had smaller diameters, while those of $\mathrm{P}, \mathrm{VW} 2.5$, VW3.5, VW4.5, VP2.5, VP3.5, VP4.5, and UW2.5 treatments were significantly thicker (Table 4).

The type of compost and the $\mathrm{EC}_{\mathrm{i}}$ significantly affected the height and diameter of the stem; besides, a significant interaction was observed in the two variables among the three $E_{i}$ levels of the three different types of compost. The height and diameter of plants decreased as $\mathrm{EC}_{\mathrm{i}}$ increased, as previously reported by Romero-Aranda et al. (2001). In the second ANOVA test, it was shown that the VW-containing substrates produced significantly taller and thicker diameter seedlings than other compost-containing substrates. UW-containing substrates produced the shortest and thinnest seedlings (Table 5 ). 


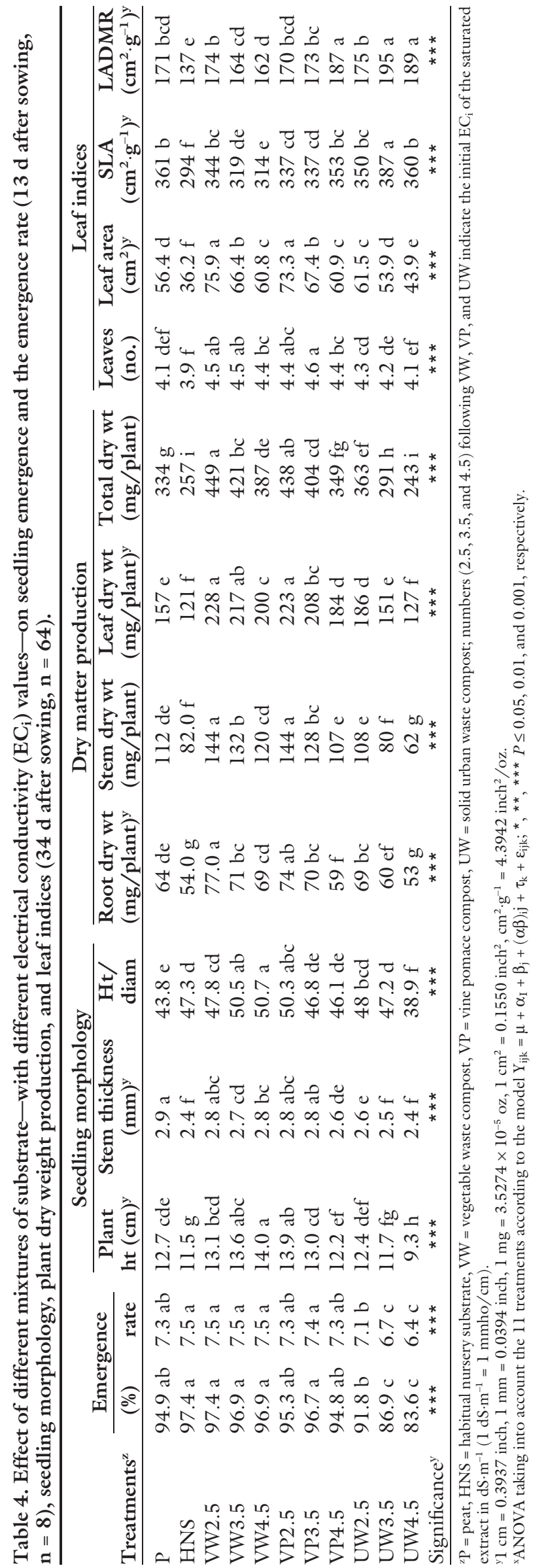

As indicated by Herrera et al. (2008), the growth of seedlings was clearly influenced by the $\mathrm{EC}_{\mathrm{i}}$ of the substrate. Furthermore, differences found between the composts and their interaction with the $\mathrm{EC}_{\mathrm{i}}$ (Table 5) show that differences in nutrient concentration of the initial mixes (Table 2 ) have an impact on the height and diameter of plants. The same effect is produced by the presence of more toxic salts at the same $\mathrm{EC}_{\mathrm{i}}$ value, for instance, the high sodium and chlorine levels found in UW compost mixes.

SubSTRATES IMPACT ON SEEDLING DRY WEIGHT. The effect of different substrates and the interaction compost type $\times \mathrm{EC}_{\mathrm{i}}$ on seedling dry weight were analyzed (Tables 4 and 5 ). Leaf, root, and total dry weights of the plants in the regular nursery substrate (HNS) and in UW4.5 were significantly smaller than in all other treatments.

UW4.5 treatment produced seedlings with the lowest stem dry weight. Treatments VW2.5 and VP2.5 produced plants with stem dry weight significantly greater than those recorded for all other treatments. VW2.5 produced the greatest root and total dry weights, showing significant differences with other treatments except with VP2.5. VW2.5 produced the greatest leaf dry weight, although there were no differences with VP2.5 and VW3.5 (Table 4). The differences seen may be associated with the $\mathrm{EC}_{\mathrm{i}}$, the higher presence of sodium and chlorine for the same $\mathrm{EC}_{\mathrm{i}}$ value, and the nutrients associated with each type of compost (Table 2).

The type of compost used as well as the $\mathrm{EC}_{\mathrm{i}}$ value had an impact on the dry weight of seedlings, besides the interaction of compost type $\times \mathrm{EC}_{\mathrm{i}}$ with all dry weight variables. For an increasing $\mathrm{EC}_{\mathrm{i}}$ (Tables 4 and 5), the UW compost had the highest impact on dry weight. Different composts with the same $\mathrm{EC}_{\mathrm{i}}$ value had different effects; therefore, the differences may be linked to the presence of nutrients and the contents of sodium and chlorine in the original mixes (Table 2). The VW compost produced plants with the largest root, shoot, leaf, and total dry weights, followed by the treatments with the VP compost, and finally those with the UW compost. Within each compost type, all dry matter variables became smaller as $\mathrm{EC}_{\mathrm{i}}$ increased. These findings had 


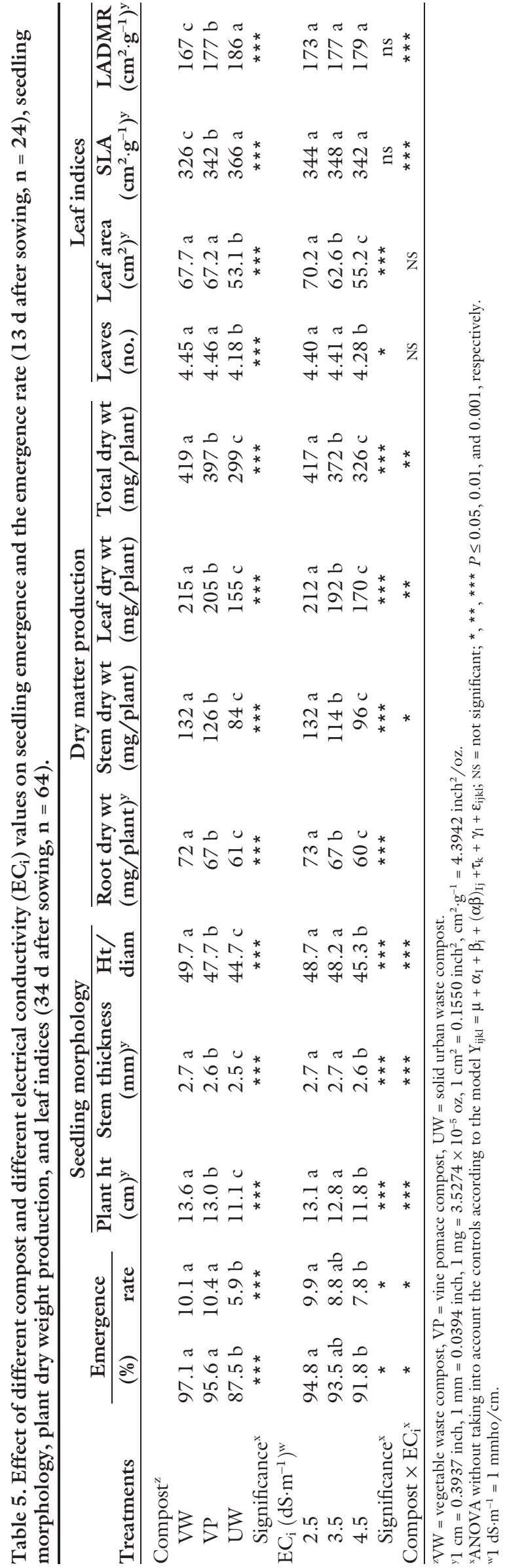

been reported before by Al-Karaki (2000), who studied the effects of sodium chloride on the roots of tomato, determining that the greater the salinity the poorer the root growth (expressed as dry matter).

EFFeCT OF SUBSTRATES ON LEAF GROWTH RATE. Substrates had a significant impact on the number of leaves produced and the leaf area. Treatment VP3.5 produced plants with the greatest number of leaves, although there were no significant differences compared with VW2.5, VW3.5, and VP2.5. Treatments VW2.5 and VP2.5 produced plants with a significantly greater leaf area than the rest of treatments. On the other hand, HNS produced the fewest leaves, although no differences were found with UW4.5 and P. UW4.5 produced plants with significantly smaller leaf area than the rest of treatments, followed by HNS ( $\mathrm{Ta}-$ ble 4 ).

The UW compost was significantly worse in terms of number of leaves produced and leaf area, probably because of high concentrations of sulfates, chlorides, and sodium (Table $2)$. The interaction compost type $\times$ $\mathrm{EC}_{\mathrm{i}}$ had no significant effect on these variables (Table 5). Other authors (Al-Karaki, 2000; Romero-Aranda et al., 2001) have reported that the values of both variables decrease depending on the stress term, the plant species, and the cultivar involved.

Plants in HNS treatment had SLA and LADMR values significantly smaller than those grown under all other conditions, so their leaves were more compact and dense. As Herrera et al. (2008) reported, this finding suggests that these plants show greater resistance to transplantation stress despite their poorer morphology and their lower dry weight values (Table 4). The VW compost was associated with significantly lower SLA and LADMR values than VP and UW composts. In contrast, $\mathrm{EC}_{\mathrm{i}}$ had no influence on SLA and LADMR values, although the interaction compost type $\times \mathrm{EC}_{\mathrm{i}}$ did have a significant influence. Each type of compost showed a different behavior when $\mathrm{EC}_{\mathrm{i}}$ changed (Table 5).

\section{Conclusions}

The final germination percentage, emergence rate, plant morphology, and dry weight values were all 
found to be strongly affected by the $\mathrm{EC}_{\mathrm{i}}$ values of the substrates, as well as by their composition. Different compost-containing mixes with the same $\mathrm{EC}_{\mathrm{i}}$ value had different effects on germination, emergence, and the quality of seedlings produced as a consequence of high sodium and chlorine levels found in the original mix.

Partial substitution of peat by compost in nursery tomato seedbed substrate is viable; however, the ratio depends upon the physical and chemical characteristics of the compost used.

When substrates are prepared, VW and VP compost ratio should not lead to a resulting mix with an $\mathrm{EC}_{\mathrm{i}}$ higher than $2.5 \mathrm{dS} \cdot \mathrm{m}^{-1}$. Stronger concentration of nutrients in VP and VW composts will promote better plant growth; although such effect does not necessarily mean that the plant quality will be higher. Plants grown in regular nursery substrates had the lowest SLA and LADMR values. Indeed, if the substrate already has high nutrient concentration levels, growers would save money by not having to apply high fertilization rates. Furthermore, the resulting seedlings would be more compact and presumably more resistant to transplantation despite their poorer morphological characteristics and lower dry weight.

\section{Literature cited}

Abad, M., P. Noguera, and C. Carrión. 2004. Los sustratos en los cultivos sin suelo, p. 113-158. In: M. Urrestarazu (ed.). Tratado de cultivo sin suelo. MundiPrensa, Madrid, Spain.

Abad, M., P. Noguera, and S. Bures. 2001. National inventory of organic wastes for use as growing media for ornamental potted plant production: Case study in Spain. Bioresour. Technol. 77:197-200.

Al-Karaki, G.N. 2000. Growth, sodium, and potassium uptake and translocation in salt stressed tomato. J. Plant Nutr. 23:369-379.

Bernal, M.P. and D.M. Gondar. 2008. Producción y gestión de los residuos orgánicos, p. 10-4l. In: J. Moreno and R. Moral (eds.). Compostaje. Mundi-Prensa, Madrid, Spain.

Bethke, P.C., L.G.L. Libourel, V. Reinohl, and R.L. Jones. 2006. Sodium nitroprusside, cyanide, nitrite, and nitrate break arabidopsis seed dormancy in a nitric oxide-dependent manner. Planta 223:805812.

Burés, S. 1997. Sustratos. Agrotécnicas S.L., Madrid, Spain.

Bustamante, M.A., C. Paredes, R. Moral, E. Agulló, M.D. Pérez-Murcia, and M. Abad. 2008. Composts from distillery wastes as peat substitutes for transplant production. Resour. Conserv. Recycling 52:792-799.

Carmona, E. and M. Abad. 2008. Aplicación del compost en viveros y semilleros, p. 397-424. In: J. Moreno and R. Moral (eds.). Compostaje. Mundi-Prensa, Madrid, Spain.

Castillo, J.E., F. Herrera, R.J. LopezBellido, F.J. Lopez-Bellido, L. LopezBellido, and E.J. Fernández. 2004. Municipal solid waste (MSW) compost as a tomato transplant medium. Compost Sci. Util. 12:86-92.

Cuartero, J. and R. Fernández-Muñoz. 1999. Tomato and salinity. Scientia Hort. 78:83-125.

Foolad, M.R. and G.Y. Lin. 1997. Genetic potential for salt tolerance during germination in Lycopersicon species. HortScience 32:296-300.

García-Gómez, A., M.P. Bernal, and A. Roig. 2002. Growth of ornamental plants in two composts prepared from agroindustrial wastes. Bioresour. Technol. 83:81-87.

Gómez, K.A. and A.A. Gómez. 1984. Statistical procedures for agricultural research. Wiley, New York.

Hendricks, S. and R. Taylorson. 1974. Promotion of seed germination by nitrate, nitrite, hydroxylamine, and ammonium salts. Plant Physiol. 54:304-309.

Herrera, F., J.E. Castillo, A.F. Chica, and L. Lopéz-Bellido. 2008. Use of municipal solid waste compost (MSWC) as a growing medium in the nursery production of tomato plants. Bioresour. Technol. 99:287-296.

Khan, M.A. and I.A. Ungar. 1998. Germination of salt tolerant shrub Suaeda fruticosa from Pakistan: Salinity and tem- perature responses. Seed Sci. Technol. 26:657-667.

Kostow, O., Y. Tzvetkov, N. Kaloianova, and O. VanCleemput. 1996. Production of tomato seedlings on composts of vine branches and grape prunings, husks and seeds. Compost Sci. Util. 4:55-61.

Lemaire, F., A. Dartigues, and L.M. Riviere. 1985. Properties of substrate made with spent mushroom compost. Acta Hort. 1972:13-29.

Pérez-Murcia, M.D., R. Moral, J. MorenoCaselles, A. Perez-Espinosa, and C. Paredes. 2006. Use of composted sewage sludge in growth media for broccoli. Bioresour. Technol. 97:123-130.

Raviv, M. 1998. Horticultural uses of composted material. Acta Hort. 469: 225-234.

Raviv, M., Y. Chen, and Y. Inbar. 1986. Peat and peat substitutes as growth media for container-grown plants, p. 257-287. In: Y. Chen and Y. Avnimelech (eds.). The role of organic matter in modern agriculture. Martinus Nijhoff, Dordrecht, The Netherlands.

Ribeiro, H.M., A.M. Romero, H. Pereira, P. Borges, F. Cabral, and E. Vasconcelos. 2007. Evaluation of a compost obtained from forestry wastes and solid phase of pig slurry as a substrate for seedlings production. Bioresour. Technol. 98:32943297.

Richards, L.A. (ed.). 1954. Diagnosis and improvement of saline and alkali soils. U.S. Dept. Agr., Agr. Hdbk No. 60.

Romero-Aranda, R., T. Soria, and J. Cuartero. 2001. Tomato plant-water uptake and plant-water relationships under saline growth conditions. Plant Sci. 160:265-272.

Scofield, C.S. 1940. Salt balance in irrigated areas. J. Agr. Res. 61:17-39.

Srinivas, T.R. 2001. Salinity tolerance of tomato germplasm during germination. Seed Sci. Technol. 29:673-677.

Sterrett, S.B. 2001. Compost as horticultural substrates for vegetable transplant production, p. 227-240. In: P.J. Stoffella and B.A. Kahn (eds.). Compost utilization in horticultural cropping systems. Lewis, Boca Raton, FL.

Wright, R.D. 1986. Pour through nutrient extraction procedure. HortScience 21:227-229. 